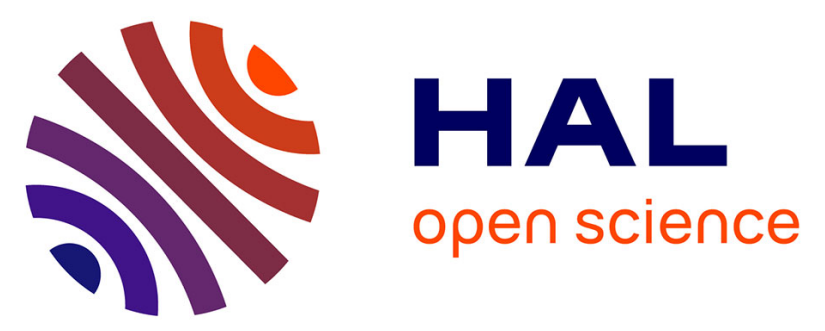

\title{
INFLUENCE OF PREPARATION PROCESS ON PHYSICAL PROPERTIES AND DEVITRIFICATION OF Li2B2O4 $(0,9)$ LiFe5O8 $(0,1)$ GLASSES
}

\author{
C. Martin, C. Chaumont, J.P. Sanchez, J.C . Bernier
}

\section{- To cite this version:}

C. Martin, C. Chaumont, J.P. Sanchez, J.C . Bernier. INFLUENCE OF PREPARATION PROCESS ON PHYSICAL PROPERTIES AND DEVITRIFICATION OF Li2B2O4 $(0,9)$ LiFe5O8 (0,1) GLASSES. Journal de Physique Colloques, 1985, 46 (C8), pp.C8-585-C8-589. 10.1051/jphyscol:1985893 . jpa-00225246

\section{HAL Id: jpa-00225246 \\ https://hal.science/jpa-00225246}

Submitted on 1 Jan 1985

HAL is a multi-disciplinary open access archive for the deposit and dissemination of scientific research documents, whether they are published or not. The documents may come from teaching and research institutions in France or abroad, or from public or private research centers.
L'archive ouverte pluridisciplinaire HAL, est destinée au dépôt et à la diffusion de documents scientifiques de niveau recherche, publiés ou non, émanant des établissements d'enseignement et de recherche français ou étrangers, des laboratoires publics ou privés. 
INFLUENCE OF PREPARATION PROCESS ON PHYSICAL PROPERTIES AND DEVITRIFICATION OF $\mathrm{Li}_{2} \mathrm{~B}_{2} \mathrm{O}_{4}(0,9)$ LiFe $_{5} \mathrm{O}_{8}(0,1)$ GLASSES

C. Martin, C. Chaumont, J.P. Sanche $z^{\star}$ and J.C. Bernier

Département Science des Matériaux, E.N.S.C.S. ${ }^{+}$, 1 rue Blaise Pascal, 67008 Strasbourg Cedex, France

"Centre de Recherches Nucléaires, B.P. 20 CR, 67037 Strasbourg Cedex, France

Réguaé: L'hypertrempe du mélange $\mathrm{L}_{1} \mathrm{~B}_{2} \mathrm{O}_{4}(0,9)-\mathrm{L}_{1} \mathrm{Fe}_{5} \mathrm{O}_{8}(0,1)$ a été réaligêe en faisant varier la temperature du bain fondu et la vitesse des rouleaux.Les changements de proprietés physiques et du processus de dévitrification de ces verres résultent de la variation de la teneur en $\mathrm{LiFe}_{5} \mathrm{O}_{8}$ ou de $I^{\prime}$ apparition de $\mathrm{Fe}^{2+}$. La nature de $\mathrm{I}^{\prime}$ amorphe ne varie pas.

Abstract: Double roller quenching of $\mathrm{LI}_{2} \mathrm{~B}_{2} \mathrm{O}_{4}(0.9)-\mathrm{LFe}_{5} \mathrm{O}_{8}(0.1)$ has been performed with various melt temperatures and roller. speeds. The changes in physical properties or in the devitrification process of the amorphous samples are shown to be related to the $\mathrm{LiFe}_{5} \mathrm{O}_{8}$ content variations or to the $\mathrm{Fe}^{2+}$ appearance but not to structural changes of the amorphous state due to preparation processes

\section{1 - INTRODUCTION}

Structures and thermodynamic states of glasses are fixed by their composition but also by the freezing-in process at the glass transition $\mathrm{Tg}$. Experimental and theoretical work has shown that glasses with same chemical composition can have different structures and physical properties (1), (2), (3), (4). We report here results on $i)$ the influence of both the melt temperature and the roller speed (i.e. the cooling rate) on the phyaical properties of ternary oxides of nominal composition $\mathrm{Li}_{2} \mathrm{~B}_{2} \mathrm{O}_{4}(0.9)-\mathrm{LiFe}_{5} \mathrm{O}_{8}(0.1)$ obtained by double roller quenching method $i j)$ the influence of the preparation process on the crystallization behaviour of these glasses. Special attention has been paid to the behaviour of glasses heated at temperatures close to Tg. Physical properties of glasses of this composition have already been studied (5), (6). Curie Weiss behaviours with large negative paramagnetic Curie temperature are observed at high temperature ( $100 K$ ), while depressed $\mu_{\text {eff }}$ are demonstrated at low temperature $;$ apin glass transition is evidenced nearly $3 K$.

\section{2 - IMFLUENCE OF MELT. TEHPERATURE AND ROLLER SPEED OH THE PHYSICAL PROPERTIES OF THE GLASSES.}

\section{1 - Sample preparation.}

A nominal composition melt $\mathrm{Li}_{2} \mathrm{~B}_{2} \mathrm{O}_{4}(0.9)-\mathrm{LiFe}_{5} \mathrm{O}_{8}(0.1)$ has been quenched by double roller technique :

first for six temperatures ranging from 850 to $1300^{\circ} \mathrm{C}$ with a constant peripherical speed velocity of $20 \mathrm{~m} / \mathrm{s}$.

Second, for constant temperature $1200^{\circ} \mathrm{C}$ but with various peripherical velocities from $1 \mathrm{~m} / \mathrm{s}$ to $34 \mathrm{~m} / \mathrm{s}$.

The brittle flakes obtained are not entirely amorphous. Some of them are partially cryatalized and contain small ferrimagnetic Life ${ }^{\circ} 8$ particles. The lightly ground quenched sample is sorted with a magnet and the non-magnetic part is checked by $X$-Ray diffraction and electron microscopy. The room temperature 
magnetization curves of the non magnetic part show a linear field dependence in addition to a very weak ferrimagnetic component due to some $L_{i F e}{ }^{0} 8$ crystallites. Therefore the crystallized LiFe $5_{8}{ }_{8}$ content of every amorphous sample can be determined. The totality of $\mathrm{LiFe}_{5} \mathrm{O}_{8}$ is shown to crystallize after twelve hours annealing at $700^{\circ} \mathrm{C}$. Magnetization measurements of the annealed samples allow the determination of the total LiFe ${ }_{5} \mathrm{O}_{8}$ content of each sample to be made.

\section{2 - Helt teaperature influence.}

A previous paper (7) has established that the starting melt temperature influences the physical properties of the glasses through a change of chemical composition. Melt temperatures below $1100^{\circ} \mathrm{C}$ (which is approximatively the liquidus temperature) result in glasses with iron content ( $\mathrm{Fe}^{3+}$ ions) below the nominal concentration, as expected from the semi-binary diagram of the $\mathrm{Li}_{2} \mathrm{~B}_{2} \mathrm{O}_{4}-\mathrm{LiFe}_{5} \mathrm{O}_{8}$ system. On the other hand if the melt temperature is above $1100^{\circ} \mathrm{C}$ the iron concentration is close to the nominal one but the iron ions occur in both $\mathrm{Fe}^{3+}$ and $\mathrm{Fe}^{2+}(<20 \%)$ oxidation states.

\section{3 - Bollers speed influence.}

Glasses obtained at different cooling rates by quenching the melt at $1200^{\circ} \mathrm{C}$ have the same chemical composition (close to the nominal one) but different thicknesses (Table 1). The amount of amorphous flakes increases with roller speed up to 20 $\mathrm{m} / \mathrm{s}$. Above this value the contact-time of the melt with the rollers is too short to ensure an efficient cooling.

Table 1:

\begin{tabular}{|c|c|c|c|c|c|}
\hline $\begin{array}{c}\text { Peripherical } \\
\text { roller speed } \\
\mathrm{m} / \mathrm{s}\end{array}$ & $\begin{array}{c}\text { Flakes } \\
\text { thickness } \\
\qquad(\mu \mathrm{m})\end{array}$ & $\begin{array}{l}\text { amorphous } \\
\text { percent } \\
\text { (wt } x \text { ) }\end{array}$ & R.x. & $\begin{array}{l}\text { Total Life } 5_{8}{ }^{\circ} \\
\text { content (mol } \mathrm{x} \text { ) }\end{array}$ & $\begin{array}{l}\text { (wty.) crystallized } \\
\text { Life }{ }_{5}{ }_{8} \text { fraction in } \\
\text { the amorphous part }\end{array}$ \\
\hline 1 & 70 & 27 & Amorphous & 9.4 & 1.53 \\
\hline 2 & 50 & 27 & Amorphous & 9.3 & 1.18 \\
\hline 5 & 30 & 53 & Amorphous & 9.4 & 1.05 \\
\hline 20 & 20 & 71 & Amorphous & 9.6 & 0.82 \\
\hline 34 & 20 & 42 & Amorphous & 9.8 & 2.40 \\
\hline
\end{tabular}

The local order of the amorphous samples has been investigated by M8ssbauer spectroscopy. Assuming Lorentzian line shapes the Mbssbauer spectra of each amorphous compound can be satisfactorily analyzed as a superposition of three quadrupole doublets with diferent isomer shifts and quadrupole splittings characterizing. Fe ${ }^{3+}$ ions in both octahedral an tetrahedral coordinations ( 6 ). The asymmetry of the quadrupole doublet of $\mathrm{Fe}^{2+}$ has been introduced in the $\mathrm{f}$ itting program to take into account previous observations (8) (9). MBssbauer results demonstrate that the cooling rate has no effect on the nature of the local order (at least in the investigated range).

The evolution of the susceptibility versus temperature (from 4.2 to $300 \mathrm{~K}$ ) as well as the magnetization versus magnetic field (at 7 or 300K) are similar for all the amorphous samples (within the experimental errors) and agree with the previous conclusion. 


\section{3 - DEVITRIFICATION PROCESS}

Devitrification process has been investigated by DTA and X Ray diffraction. Devitrification proceeds by the crystallization of LiFe ${ }_{5}{ }_{8}$ and lithium borate phases $\mathrm{LiBO}_{2} \alpha$, LiBO ${ }_{2} \gamma$ (respectively a monoclinic form and a tetragonal form of metaborates (10)) and one (or more) other borate phase, called $\mathrm{LiBO}_{2} \mathrm{X}$, that has not yet been referenced in the literature. This latter phase appears also during the devitrification process of $0.5 \mathrm{Li}_{2} \mathrm{O}-0.5 \quad \mathrm{~B}_{2} \mathrm{O}_{3}$ glasses and its $X \mathrm{ray}$ diffraction diagram is very similar to the one observed during the dehydradation process of $\mathrm{LiBO}_{2} \mathrm{8H}_{2} \mathrm{O}$ (to be published). This suggests that slight hydratation could be responsible for the appearance of this phase.

A typical DTA curve performed in air $(2 \% / \mathrm{mn})$ is shown in figure 1 where the different DTA peaks are assigned as follows :

Fig.l.

1 : reoxidation of $\mathrm{Fe}^{2+}$.

2 : endothermal ef fect due to the glass transition.

3 : crystallization of $\mathrm{LiFe}_{5}{ }^{0} \mathrm{~g}$.

4 : crystallization of a Lithium borate phase $\left(\mathrm{LiBO}_{2} \alpha\right.$ or $\left.\mathrm{LiBO}_{2} \mathrm{X}\right)$.

5 : crystallization of $\mathrm{LiBO}_{2} \mathrm{X}$.

6 : transformation $\mathrm{LiBO}_{2} \mathrm{X} \longrightarrow \mathrm{LiBO}_{2} \alpha$.

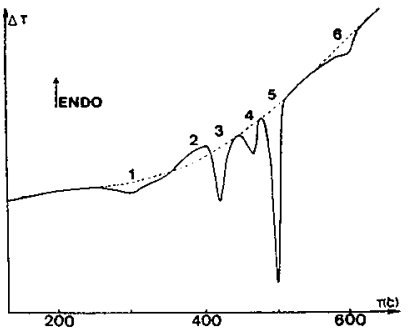

The appearance of $\mathrm{LiBO}_{2} \gamma$ in the $\mathrm{X}$ ray diffraction diagram of amorphous sample annealed at temperatures ranging from 450 to $580^{\circ} \mathrm{C}$ is due to the progressive transformation of $\mathrm{LiBO}_{2} \alpha(\mathrm{X})$ to $\mathrm{LiBO}_{2} \gamma$ as expected from the $\mathrm{Li}_{2} \mathrm{O}^{\mathrm{O}} \mathrm{B}_{2} \mathrm{O}_{3}$ diagram (10). The more developed exothermic peak corresponding to the $\mathrm{LiBO}_{2} \mathrm{X}$ crystallization is shifted to lower temperatures when using finer crushed glass powder whereas the $\mathrm{LiFe}_{5} \mathrm{O}_{8}$ crystallization peak is almost not affected. This behaviour indicates that $\mathrm{LiBO}_{2} \mathrm{X}$ and $\mathrm{LiFe}_{5} \mathrm{O}_{8}$ are respectively surface and bulk nucleated (11).

Glasses of the same composition, heated in non-oxidizing atmosphere exhibit the same DTA thermograph. In air,the $\mathrm{LiFe}_{5} \mathrm{O}_{8}$ crystallization peak is shifted to higher temperatures. This behaviour could result from oxidation of $\mathrm{Fe}^{2+}$ taking place just before $\mathrm{LiFe}_{5}{ }_{8}$ crystallization.

\section{4 - TRANSITION ZONE}

\section{1 - First results}

The endothermal effect (Fig. 1) corresponding to Tg occurs at the same temperature (within experimental error $\left(4^{\circ} \mathrm{C}\right)$ ) for all samples with the same composition quenched with various cooling rates. Glasses heated just above $\mathrm{Tg}$, show a softening point.

\section{2 - Experimental.}

Several amorphous samples of the same origin (quenched from $1100^{\circ} \mathrm{C}$ ) have been heated $(2 \% / \mathrm{mn})$ in the DTA apparatus, at different temperatures in the transition zone $\left(352,379,394,400\right.$ and $\left.405^{\circ} \mathrm{C}\right)$ and then, quenched in air.

\section{3 - Results and discussion.}

The three annealed samples at 379,400 and $405^{\circ} \mathrm{C}$ show up a decrease in susceptibility below $180 \mathrm{~K}$ with respect to the non annealed one's. The room temperature magnetization curve of the glass heated at $352^{\circ} \mathrm{C}$ is identical to the non-annealed sample. The magnetization curve of the amorphous gample annealed at $394^{\circ} \mathrm{C}$ exhibits a paramagnetic susceptibility (i.e. the slope of the linear part of the curve) slightly lower than for the non-annealed sample. Magnetization curves 
of the annealed samples at 400 and $405^{\circ} \mathrm{C}$ reveal a curvature indicating a superparamagnetic behaviour with a very smooth saturation (Fig.2).

Mossbauer spectrum, at $4.2 \mathrm{~K},(\mathrm{Fig.3})$ of the annealed sample at $379^{\circ} \mathrm{C} 1 \mathrm{~s}$ identical to virgin-sample whereas the glass annealed at $394^{\circ} \mathrm{C}$ presents a better resolved hyperfine structure (Fig.3). It is concluded that the spin glass freezing temperature (6) has increased with thermal treatment. The spectra of the annealed samples at 400 and $405^{\circ} \mathrm{C}$ (Fig.3) indicate an evolution toward a superparamagnetic behaviour in agreement with magnetization regults.

Fig. 2 .

Room temperature magnetization curves of:

-virgin sample: $* *$

-annealed samples at $394^{\circ} \mathrm{C}:$ : $400^{\circ} \mathrm{C}$ :

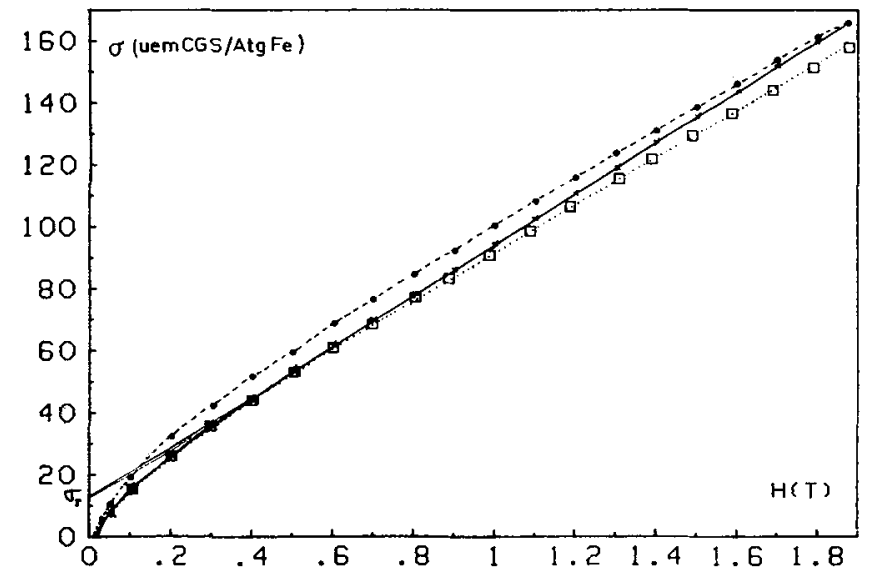

Fig. 3 .

4. 2K M8ssbauer spectra of amorphous samples annealed at different temperatures

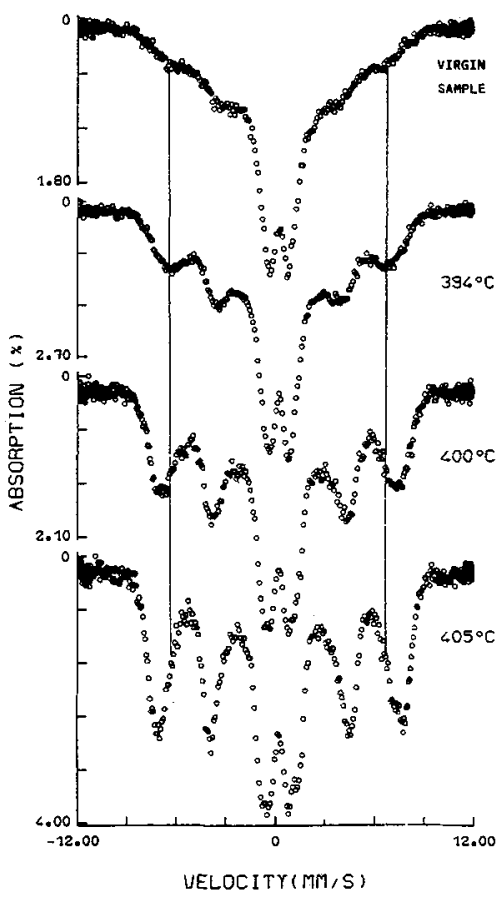




\section{Discussion:}

The freezing temperatures increase with annealing temperature within the transition zone until the beginning of $\mathrm{LiFe}_{5} \mathrm{O}_{8}$ crystallization resulting in superparamagnetic behaviour. A growing of the cluster sizes or of the antiferromagnetic interactions could support this experimental finding. Cluster growth is evident if LiFe ${ }^{\circ} 8$ nucleation process starts in the transition zone. An increase of the antiferromagnetic interactions could result from a structural rearrangement increasing the superexchange coupling. The depressed paramagnetic susceptibility could also be explained by the raise of the antiferromagnetic interactions. The whole results can be related to a relaxation process (an evolution toward a more stable amorphous structure).

Prenucleation or relaxation should occur when annealing in the transition zone.It may be questioned whether the two processes can be distinguished. For temperatures higher than $\mathrm{Tg}$, the glass viscosity falls of rapidly so diffusion processes are accelerated and consequently nucleation and crystallization processes become faster.

\section{$\underline{5 \text { - CONCLUSION. }}$}

This study demonstrates that the physical properties of these glasses are related to their composition variations or changes of valence states of minor components and not to structural changes of the amorphous state due to preparation process.

\section{REFERENCES :}

1) C. T. MOYNIHAN, A. J. EASTEAL, J. Wilder, J. Phys. Chem. 78 (1974) 2673

2) V. GOTTARDI, J. Non-cryst. Solids. 49 (1982) 4.61

3) G. S. GREST, M. H. COHEN, Phys. Rev. B. 21 (1980) 4113

4) M.BARICCO, C.BATtezzati, F.MARINO, G.RIONTINo, Proceedings V int. conf. on Rapidly quenched Metals, Wurtzburg (1984)

5) C. CHAUMONT, J. C. BERNIER, J. Sol. State. Chem. 38 (1981) 246

6) J. P. SANCHEZ, J. M. FRIEDT, J. de Phys. 43 (1982) 1707

7) C. MARTIN, C. CHAUMONT, J. P. SANCHEZ, J. C. BERnIER, Rev. Chim. Min. 21 (1984) 657

8) J. F. SANCHEZ, J. M. FRIEDT, R. HORNE, A. J. VAN DUYNEVELDT ,J. Phys. C. Sol. State phys. 17 (1984), 127

9) A. SCHNELl, J. C. BERnIER, J. P. SANCHEZ, Mat. Res. Bull. 18 (1983) 251

10) C.MARaINe - GIROUX, R.BOUAzIZ, G.PEREZ, Rev. Chim. Min. 9 (1972) 779

11) P. W. Mc MILLAN, J. Non-cryst. Solids $\underline{52}$ (1982) 67 